\title{
PENERAPAN MODEL COOPERATIVE LEARNING TIPE THINK PAIR SHARE UNTUK MENINGKATAN AKTIVITAS DAN HASIL BELAJAR MATEMATIKA SISWA KELAS VI SD NEGERI KALIWADAS 01
}

\author{
Paryanti \\ Guru SDN Kaliwadas \\ Email: spd_paryanti@yahoo.com
}

\begin{abstract}
The aims of this research were to increase the activities and the result of study by implementation of cooperative learning model type think pair share. The method of the research was Classroom Action Reserach. The instrument of data collection used observation sheet and test. Technique of data analysis used qualitative and quantitative analysis. The result showed that the student activity in cycle I 62,54\% (active) and cycle II 78,27\%(active). The result study of the cognitivie in cycle I 71,70\% (good) and cycle II 78,61\% (good).
\end{abstract}

Keywords : activity, result study, think pair share

\section{PENDAHULUAN}

Pendidikan merupakan usaha sadar untuk memanusia manusiakan akan kearah pendewasaan. Hal ini sesuaidengan Undang-undang No 20 tahun 2003, dinyatakan bahwa pendidikan adalah usaha sadar dan terencana untuk mewujudkan suasana belajar dan proses pembelajaran agar peserta didik secara aktif mengembangkan potensi dirinya untuk memiliki kekuatan spiritual keagamaan, pengendalian diri, kepribadian, kecerdasan akhlak mulia, sertaketerampilan yang diperlukandirinya, masyarakat, bangsadan Negara. Sagala (2010: 4), menyatakan bahwa pendidikan merupakan suatu proses dalam rangka mempengaruhi siswa supaya mampu menyelesaikan diri sebaik mungkin dengan lingkungannya dan yang akan menimbulkan perubahan pada dirinya yang memungkinkan, sehingga berfungsi sesuai kompetensinya dalam kehidupan masyarakat.

Kemudian Suprayekti (2004: 1) menjelaskan bahwa peningkatan mutu pendidikan adalah menjadi tanggung jawab semua pihak yang terlibat dalam pendidikan terutama bagi guru sekolah dasar, yang merupakan ujung tombak dalam pendidikan dasar. Sehingga penulis menyimpulkan bahwa pendidikan perlu mendapat perhatian yang besar supaya mutu pendidikan dapat meningkat. 
Berdasarkan hasil observasi dan wawancara dengan guru kelas VI SD Negeri Kaliwadas 01 yang dilaksanakan pada tanggal 16 Desembar 2013, didapat keterangan bahwa hasil belajar siswa pada pembelajaran matematika masih rendah atau belum mencapai Kriteria Ketuntasan Minimal (KKM) yang telah ditentukan, yaitu 66. Rendahnya hasil belajar siswa dibuktikan dari hasil Ujian Tengah Semester yang telah dilaksanakan pada semester ganjil tahun pelajaran 2013/2014 yaitu, 24 $(54,54 \%)$ dari 44 siswa belum mampu mencapai nilai KKM dan hanya $20(45,46 \%)$ siswa yang sudah mampu mencapai KKM yang telah ditentukan.

Penyebab rendahnya hasil belajar siswa adalah kondisi siswa yang kurangaktif, sertakurangnya perhatian siswa pada proses pembelajaran. Pembelajaran yang masih bersifatone way traffic communication (pembelajaran dengan komunikasi satu arah) yang berpusat pada guru cenderung membuat siswa pasif sehingga membosankan siswa. Guru belum pernah menggunakan variasi model pembelajaran cooperative learning tipe think pair sharedalam pembelajaran di kelas.

Melihat fakta tersebut maka perlu diadakan perbaikan pembelajaran agar hasil belajar siswa dapat meningkat. Upaya perbaikan pembelajaran berkaitan erat dengan inovasi pembelajaran, salah satu bentuk inovasi pembelajaran yaitu menerapkan pembelajaran yang bermakna dan menyenangkan melalui Penelitian Tindakan Kelas (PTK). Menurut Muslikah (2010: 32) PTK adalah suatu bentuk penelitian yang bersifat reflektif dengan melakukan tindakan-tindakan tertentu agar dapat memperbaiki dan meningkatkan praktek-praktek di kelas secara lebih profesional.

PTK perlu menggunakan strategi, pendekatan, model, metode, atau media yang dapat membantu memperbaiki kualitas pembelajaran tersebut. Namun tidak semua strategi, pendekatan, model, metode, atau media dapat digunakan untuk semua mata pelajaran. Seperti teori kognitif yang dipaparkan oleh Piaget (Sumantri, 2007: 1.15) bahwa siswa pada usia 7-11 tahun berada pada tahap operasional konkret, sehingga dalam pembelajaran siswa harus dihadapkan dengan permasalahan yang konkret dan relevan dengan kehidupannya.

Berdasarkan masalah tersebut, penerapan model cooperative learning tipethink pair share dapat dikatakan sebagai alternatif yang tepat. Isjoni (2010: 78) menyatakan bahwa tehnik ini memberikan siswa kesempatan untuk bekerja sendiri serta bekerja sama dengan orang lain. Keunggulan teknik ini adalah optimalisasi partisipasi siswa, yaitu memberi kesempatan 
delapan kali lebih banyak kepada siswa untuk dikenali dan menunjukkan partisipasi mereka kepada orang lain. Sedangkan Huda (2013: 206) menyatakan bahwa strategi think pair share memperkenalkan gagasan tentang waktu 'tunggu atau berfikir' (wait or think time) pada elemen pembelajaran kooperatif yang saat ini menjadi salah satu faktor ampuh dalam meningkatkan respons siswa terhadap pertanyaan.

Bertolak dari paparan di atas perlu dilakukan perbaikan kualitas pembelajaran melalui penelitian tindakan kelas. Berkaitan dengan penelitian ini, peneliti mengambil judul "Penerapkan Model Cooperative Learning Tipe Think Pair Shareuntuk Meningkatkan Aktivitas dan Hasil Belajar Matematika Siswa Kelas VI SD Negeri Kaliwadas 01”.

Beranjak dari uraian di atas, maka tujuan dari pelaksanaan penelitian ini adalah untuk meningkatkan aktivitas dan hasil belajar siswa kelas VI SDN Kaliwadas 01melalui penerapan model cooperative learning tipe think pair sharetahun pelajaran 2013/2014.

Sedangkan manfaat yang diharapkan dari penelitian tentang penerapan model cooperative learning tipe think pair share untuk meningkatkan aktivitas dan hasil belajarpada pembelajaran matematika siswa kelas VI SDN Kaliwadas 01tahun pelajaran 2013/2014 sebagai berikut:
1. Bagi siswa, dapat meningkatkan aktivitas dan hasil belajar pada pembelajaran matematika melalui penerapan model cooperative learning tipe think pair share.

2. Bagi guru, dapat meningkatkan kinerja dan profesionalisme guru dalam penyelengaraan pembelajaran di kelas dengan menerapkan model cooperative learning tipe think pair share secaratepat.

3. Bagi sekolah, sebagai acuan untuk mengoptimalkan pembelajaran dalam upaya meningkatkan kualitas pembelajaran di SD Negeri Kaliwadas 01.

4. Bagi peneliti, dapat menambah wawasan dan pengetahuan tentang penelitian tindakan kelas dengan penerapan model cooperative learning tipe think pair share, agar kelak ketika menjadi seorang guru mampu menjalankan tugas dan pekerjaannya secara professional.

\section{METODE PENELITIAN}

Penelitian ini menggunakan metode penelitian tindakan kelas (PTK) yang dalam bahasa asing dikenal sebagai classroom action research, yang berarti action research (penelitian denga tindakan) yang dilakukan di kelas. Mulyasa (2011: 88) mendefinisikan pengertian penelitian tindakan kelas merupakan suatu cara 
memperbaiki dan meningkatkan profesionalisme guru, karena guru merupakan orang yang paling tahu segala sesuatu yang terjadi dalam pembelajaran.

Penelitian dilaksanakan dua siklus yang terdiri dari perencanaan, pelaksanaan, pengamatan, dan refleksi.

Penelitian ini telah dilaksanakan di kelas VI SD Negeri Kaliwadas 01 Kecamatan Adiwerna Kabupaten Tegal. Penelitian ini dilaksanakan pada semester genap, dengan lama penelitian 5 bulan terhitung dari bulan Desember 2013 - April 2014. Subjek penelitian tindakan kelas adalah siswa dan guru kelas VI SD Negeri Kaliwadas 01dengan jumlah 44 siswa yang terdiri dari 22 perempuan dan 22 laki-laki.

Teknik pengumpulan data menggunakan teknik tes dan non tes. Teknik tes digunakan untuk mengukur hasil belajar siswa melalui tes formatif. Teknik non tes digunakan untuk mengukur variabel berupa aktivitas siswa, dan kinerja guru melalui lembar observasi. Alat pengumpulan data menggunakan lembar observasi dan soal tes. Teknik analisis data menggunakan analisis kualitatif dan kuantitatif.

\section{HASIL PENELITIAN DAN PEMBAHASAN}

\section{a. Hasil Penelitian}

Deskripsi Awal

Penelitian ini dilaksanakan di SD Negeri Kaliwadas 01yang terletak di Kecamatan Adiwerna Kabupaten Tegal. SD Negeri Kaliwadas 01 memiliki tanah seluas lebih kurang $2.700 \mathrm{~m}^{2}$, terdiri dari 6 ruang kelas, 1 kantor guru, 1 ruang perpustakaan dan 1 ruang UKS. Kelas VI terdiri dari 1 kelas yang terdiri dari 22 siswa laki-laki dan 22 siswa perempuan. Penelitian ini dilaksanakan pada semester genap tahun pelajaran 2013/2014dalam dua siklus dengan dua kali pertemuan tiap siklusnya. Perencanaan penelitian pada siklus I secara garis besar peneliti berdiskusi dengan guru kelas VI SD Negeri Kaliwadas 01 tentang penerapan model cooperative learning tipe think pair share, melakukan analisis kurikulum untuk mengetahui kompetensi inti dan kompetensi dasar yang akan diajarkan dengan menggunakan model cooperative learning tipe think pair share, menyusun perangkat pembelajaran yaitu: pemetaan, silabus, dan rencana pelaksanaan pembelajaran (RPP), menyiapkan media pembelajaran, menyiapkan instrumen penilaian yang akan digunakan pada kegiatan pembelajaran (lembar observasi penilaian aktivitas siswa dan lembar observasi IPKG guru), dan 
ISSN 2442-5419 Vol. 4, No. 2 (2015) 72-83

menyusun alat evaluasi pembelajaran.

\section{b. Hasil Pelakasanaan Tindakan dan Observasi Siklus I}

Hasil penelitian yang diperoleh setelah pelaksanaan pembelajaran ditiap pertemuan mengalami peningkatan. Berikut merupakan rangkuman hasil penelitian yang mendeskripsikan penerapan model cooperative learning tipe think pair sharepada pembelajaran matematika.

Rekapitulasi nilai kinerja guru siklus I menunjukan bahwa guru mendapatkan nilai $70,22 \%$ dengan kategori "baik". Sedangkan hasil analisis data aktivitas belajar siswa memperoleh rata-rata sebesar $62,54 \%$ kategori "aktif".

Sedangkan nilai hasil belajar kognitif siklus I dari 44 siswa kelas VIcukup beragam. Dari nilai rata-rata tiap siswa, dapat diketahui bahwa nilai tertinggi yaitu 100 dan nilai terendah yaitu 45. Berdasarkan penjumlahan nilai rata-rata kelas tiap siswa, didapatkan nilai rata-rata kelas yaitu $71,70 \%$. Jumlah siswa yang tuntas mencapai KKM (66) sebanyak 25 siswa dengan persentase ketuntasan secara klasikal adalah 56,82\% dengan kategori "sedang".

\section{c. Refleksi Siklus I}

Berdasarkan hasil observasi pada siklus I, dalam penelitian tindakan kelas ini diperoleh data antara lain:

1) Mengaitkan materi dengan pengetahuan lain yang relevan

2) Menyampaikan materi sesuai dengan hirarki belajar

3) Mengaitkan materi dengan realitas kehidupan

4) Memfasilitasi kegiatan yang memuat komponen eksplorasi, elaborasi, dan konfirmasi

5) Melaksanakan pembelajaran secara runtut

6) Menguasai kelas

7) Melaksanakan pembelajaran yang memungkinkan tumbuhnya kebiasaan yang positif (nurturant effect)

8) Melaksanakan pembelajaran dengan menggunakan model cooperative learning tipe think pair share sesuai dengan alokasi waktu yang direncanakan

9) Menunjukkan keterampilan dalam penggunaan media

10) Menghasilkan pesan yang menarik

11) Menggunakan media secara efektif dan efisien

12) Melibatkan siswa dalam pemanfaatan media

13) Menumbuhkan partisipasi aktif siswa dalam pembelajaran

14) Memfasilitasi terjadinya interaksi guru, siswa, dan sumber belajar 


\section{d. Hasil Pelakasanaan Tindakan dan Observasi Siklus II}

Setelah dilakukan pembelajaran di siklus II diperoleh rata-rata kinerja guru yaitu sebesar $82,29 \%$ dengan kategori "baik". Sedangkan hasil analisis data aktivtas siswa memperoleh nilai rata-rata yaitu $78,27 \%$ kategori "aktif".

Nilai rata-rata hasil belajar kosnitif tiap siswa, dapat diketahui bahwa nilai tertinggi yaitu 100 dan nilai terendah yaitu 50 . Berdasarkan penjumlahan nilai seluruh siswa, didapatkan nilai rata-rata kelas yaitu $78,61 \%$. Jumlah siswa yang tuntas mencapai KKM (66) sebanyak 37 siswa dengan persentase ketuntasan secara klasikal adalah $84,09 \%$ dengan kategori "sangat tinggi”.

\section{e. Refleksi Siklus II}

Berdasarkan penelitian yang telah dilakukan terhadap pelaksanaan siklus II, pada pembelajaran matematika dengan menerapkan model cooperative learning tipe think pair share telah memenuhi indikator keberhasilan yang telah ditentukan, yaitu:

1) Terdapat peningkatan aktivitas dan hasil belajar matematika siswa kelas VI SDN
Kaliwadas 01 pada setiap siklusnya.

2) Pada akhir penelitian siswa dinyatakan tuntas apabila siswa yang mencapai KKM 66 mencapai $\geq 75 \%$ dari jumlah siswa pada kelas VI yang diteliti yaitu 44 siswa.

Hal ini dibuktikan dengan presentase aktivitas belajar siswa pada siklus II sebesar $81,81 \%$. Kemudian presentase hasil belajar pada siklus II sebesar 84,09\%. Sedangkan presentase rata-rata kinerja guru pada siklus II sebesar $82,29 \%$.

Berdasarkan hasil pada siklus II maka tindakan pada siklus penelitian dihentikan, karena hasil yang diharapkan sudah tercapai yaitu aktivitas dan hasil belajar siswa sudah mengalami peningkatan dari siklus I sampai dengan siklus II.

\section{f. Pembahasan}

\section{1) Kinerja Guru}

Berdasarkan hasil observasi yang dilakukan observer (teman sejawat) menggunakan lembar instrumen.

Pelaksanaan pembelajaran menggunakan model cooperative learning tipe think pair share sudah berjalan dengan baik, dapat dilihat pada tabel berikut.

Tabel 1. Rekapitulasi nilai kinerja guru siklus I dan siklus II.

\begin{tabular}{|c|l|c|c|}
\hline No & \multicolumn{1}{|c|}{ Aspek } & Siklus I & Siklus II \\
\hline 1 & Nilai rata-rata & $70,22 \%$ & $82,29 \%$ \\
\hline 2 & Kategori & Baik & Sangat Baik \\
\hline 3 & Peningkatan nilai rata-rata & \multicolumn{2}{|c|}{$12,07 \%$} \\
\hline
\end{tabular}


ISSN 2442-5419 Vol. 4, No. 2 (2015) 72-83

Untuk melihat lebih jelas terjadinya peningkatan kinerja guru, maka peneliti menyajikan gambar diagram berikut.

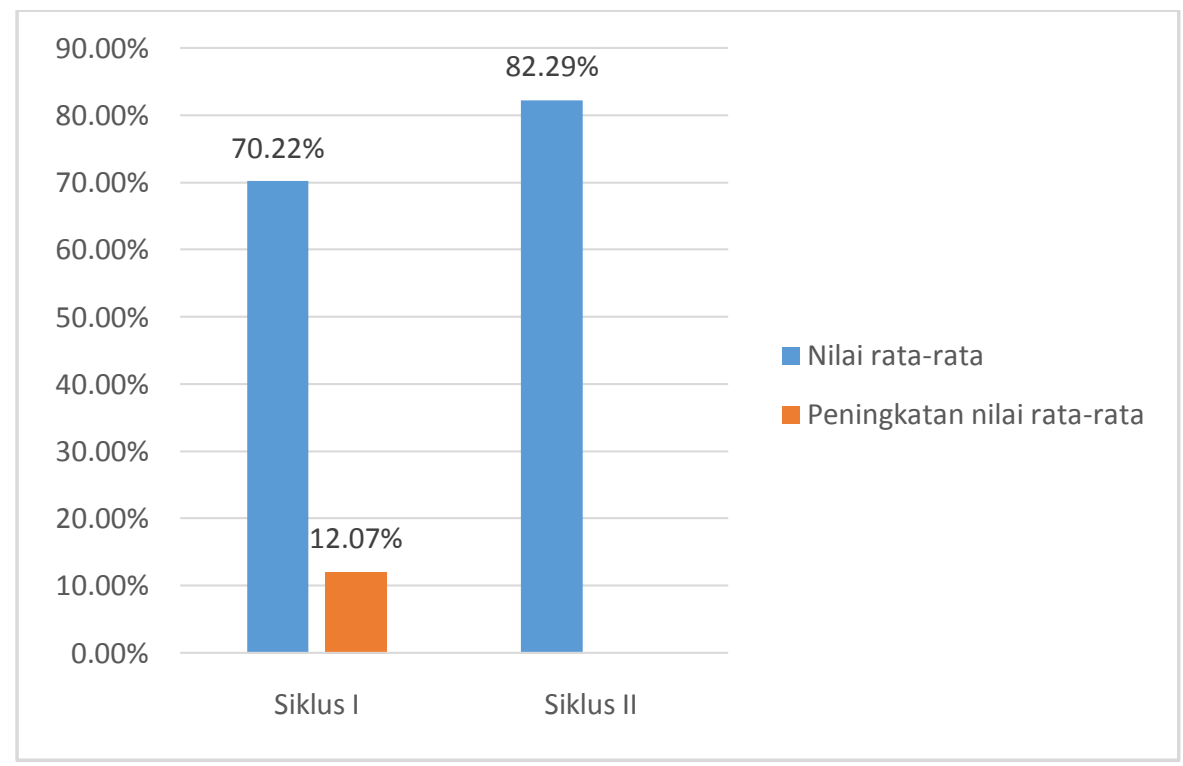

Gambar 1. Nilai Kinerja Guru per-siklus

Berdasarkan tabel 1 dan gambar 1 dapat diamati bahwa kinerja guru mengalami peningkatan pada tiap siklus pembelajaran yang dilaksanakan. Rata-rata kinerja guru pada siklus I sebesar 70,22\% dengan kategori kinerja baik dan meningkat pada siklus II menjadi 82,29\% dengan kategori sangat baik. Hal tersebut menunjukkan bahwa terjadi peningkatan rata-rata kinerja guru sebesar 12,07\%. Hal ini menunjukkan bahwa kinerja guru pada saat pembelajaran berlangsung mengalami peningkatan disetiap siklusnya sebagaimana digambarkan pada grafik yang terus meningkat.

\section{2) Aktivitas Belajar Siswa}

Analisis data terhadap hasil penelitian setelah mengikuti pembelajaran dengan menggunakan model cooperative learning tipe think pair share pada SDN Kaliwadas 01 adalah sebagai berikut. 
ISSN 2442-5419 Vol. 4, No. 2 (2015) 72-83

Tabel 2. Rekapitulasi persentase aktivitas siswa siklus I dan siklus II.

\begin{tabular}{|c|l|c|c|}
\hline No & \multicolumn{1}{|c|}{ Aspek } & Siklus 1 & Siklus II \\
\hline 1 & Rata-rata & $62,54 \%$ & $78,27 \%$ \\
\hline 2 & Peningkatan Rata-rata & \multicolumn{2}{|c|}{$15,73 \%$} \\
\hline 3 & Presentase Ketuntasan klasikal & $52,27 \%$ & $81,82 \%$ \\
\hline 4 & Peningkatan Presentase & \multicolumn{2}{|c|}{$29,55 \%$} \\
\hline
\end{tabular}

\begin{tabular}{|c|c|c|}
\hline ningkata & aktivitas & pembelajaran dapat diamati pad \\
\hline
\end{tabular}

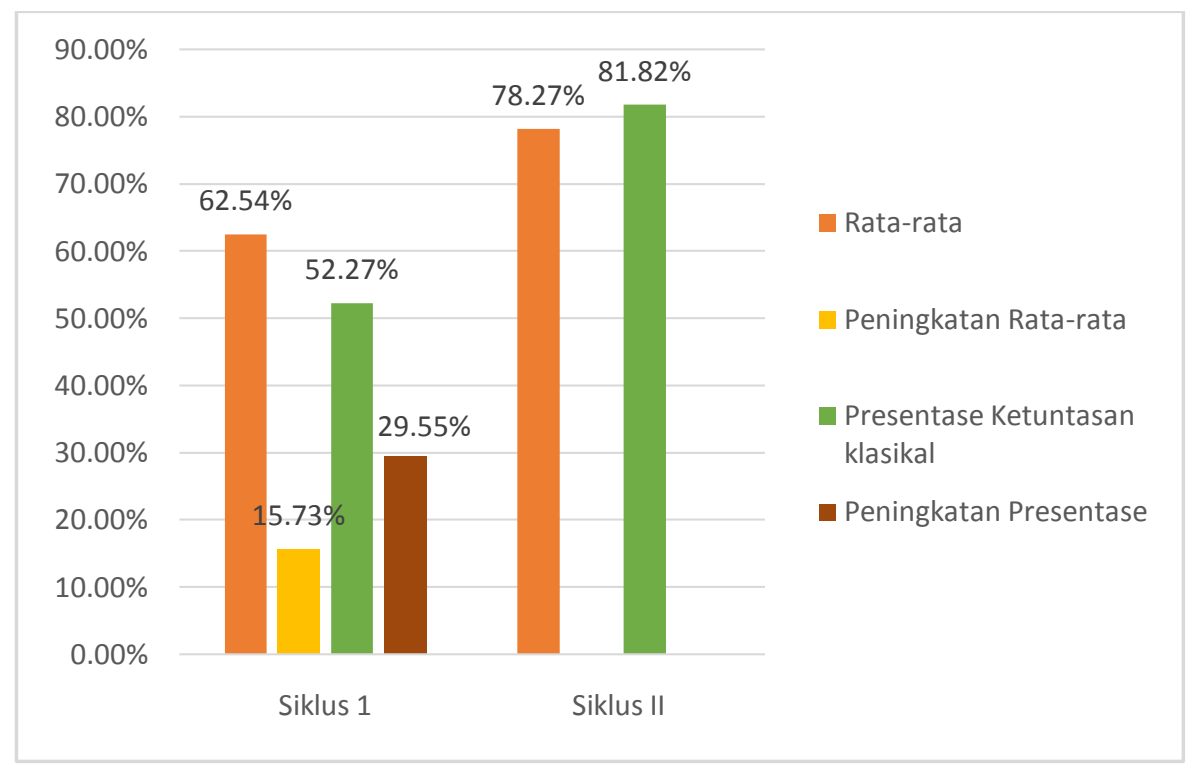

Gambar 2. Persentase Aktivitas Belajar Siswa per-Siklus.

Berdasarkan tabel 2 dan gambar 2 diketahui bahwa aktivitas siswa mengalami peningkatan disetiap siklus. Persentase aktivitas klasikal diperoleh melalui rata-rata kemunculan indikator dalam pembelajaran. Pada siklus I memperoleh nilai rata-rata aktivitas klasikal sebesar $62,54 \%$ dengan kategori "aktif" dan siklus II mencapai $78,27 \%$ dengan kategori "aktif". Presentase aktivitas siswa mengalami peningkatan sebesar $15,73 \%$. Sedangkan presentase ketuntasan siswa klasikal siklus I sebesar $52,27 \%$ dan siklus II sebesar $81,81 \%$ dengan peningkatan sebesar $29,55 \%$.

Berdasarkan uraian di atas, peneliti mengambil kesimpulan bahwa peningkatan yang ditunjukkan dalam aktivitas belajar siswa membuktikan bahwa model cooperative learning tipe think pair share dapat meningkatkan aktivitas atau kegiatan belajar 
secara optimal. Hal tersebut sejalan dengan dengan pendapat Kunandar (2011: 277) aktivitas belajar adalah keterlibatan siswa dalam bentuk sikap, pikiran, perhatian, dan aktivitas dalam kegiatan pembelajaran guna menunjang keberhasilan proses belajar mengajar dan memperoleh manfaat.

\section{3) Hasil Belajar Siswa}

Hasil belajar siswa yang diperoleh dari pelaksanaan tes formatif siklus I dan II mengalami peningkatan di setiap siklusnya. Hal ini dapat dilihat antara hasil belajar siswa pada siklus I dan II terdapat kenaikan jumlah siswa yang tuntas dan penurunan jumlah siswa yang belum tuntas. Hasil belajar siswa pada siklus I dan II dapat dilihat pada tabel berikut.

Tabel 3. Rekapitulasi hasil belajar siswa siklus I dan siklus II.

\begin{tabular}{|c|l|c|c|}
\hline No. & Ketuntasan Hasil Belajar Siswa & Siklus I & Siklus II \\
\hline 1. & Nilai rata-rata & $71,70 \%$ & $78,61 \%$ \\
\hline 2. & Peningkatan Rata-rata & \multicolumn{2}{|c|}{$6,91 \%$} \\
\hline 3. & Persentase Ketuntasan & $56,82 \%$ & $84,09 \%$ \\
\hline 4 & Peningkatan Persentase & \multicolumn{2}{|c|}{$27,27 \%$} \\
\hline
\end{tabular}

Peningkatan persentase hasil belajar kognitif siswa dalam siklus

penelitian dapat juga ditunjukan pada grafik berikut.

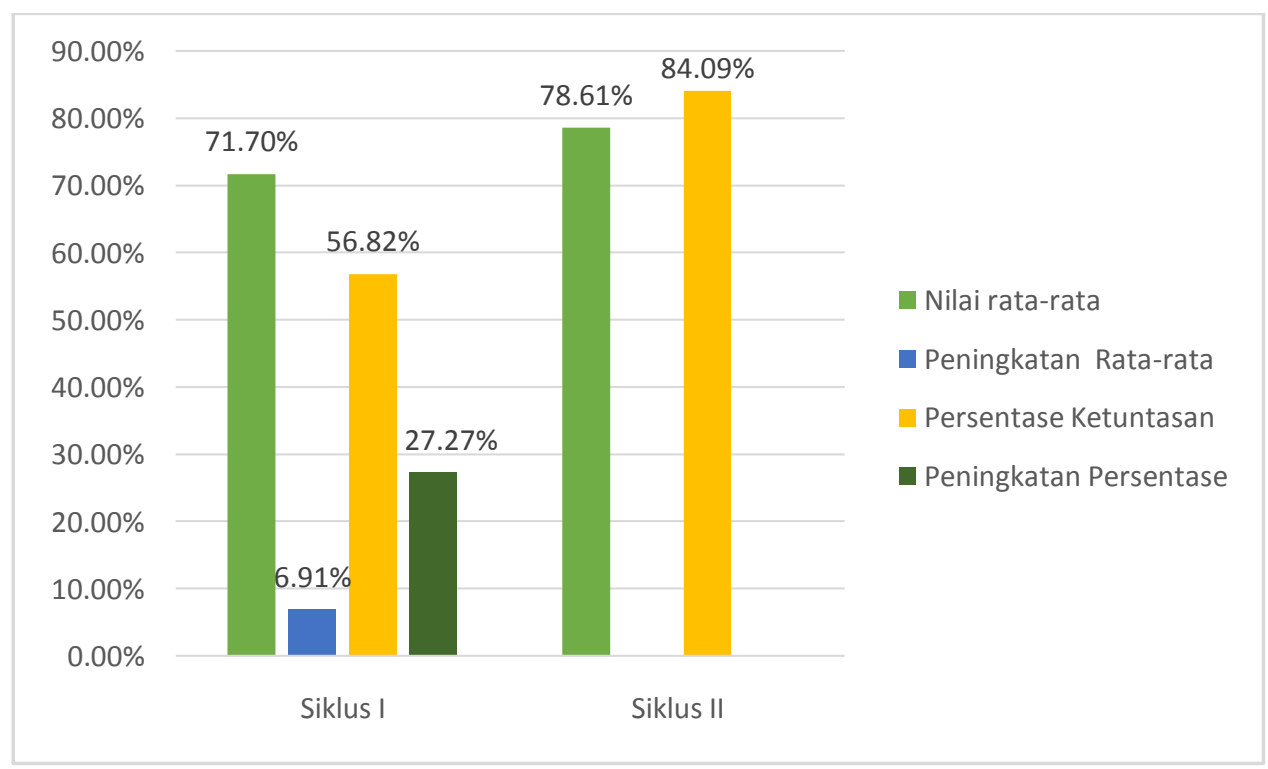

Gambar 3. Rekapitulasi Hasil Belajar Kognitif per-Siklus. 
Pada siklus I rata-rata nilai hasil belajar siswa sebesar $71,70 \%$ dengan persentase ketuntasan sebesar $56,82 \%$ sedangkan pada siklus II rata - rata meningkat sebesar $6,91 \%$ sehingga menjadi $78,61 \%$ dan persentase ketuntasan siswa secara klasikal terjadi peningkatan angka persentase menjadi 84,09\%. Peningkatan angka persentase sebesar $27,27 \%$ ini membuktikan bahwa hasil penelitian pada siklus II sudah mencapai indikator keberhasilan yang telah ditentukan.

Berdasarkan hasil penelitian menunjukkan bahwa melalui penerapan model cooperative learning tipe think pair share dapat meningkatkan aktivitas dan hasil belajar siswa, khususnya pada kelas VI SD Negeri Kaliwadas 01 tahun pelajaran 2013/2014. Hal ini sesuai dengan pendapat Isjoni (2007: 54) bahwa pembelajaran cooperative learning tipe think pair share merupakan salah satu tipe pembelajaran kooperatif yang mendorong siswa aktif dan saling membantu dalam menguasai materi pelajaran untuk mencapai prestasi yang maksimal.

\section{KESIMPULAN DAN SARAN \\ a. Kesimpulan}

Berdasarkan penelitian tindakan kelas yang dilakukan terhadap siswa kelas VI SD Negeri Kaliwadas $01 \quad$ Kecamatan Adiwerna Kabupaten Tegal pada pembelajaran mamatematikaa dengan menerapkan model cooperative learning tipe think pair share dapat disimpulkan sebagai berikut.

1. Penerapan model cooperative learning tipe think pair share sesuai langkah-langkah yang yang tepat dalam pembelajaran matematika dapat meningkatkan aktivitas belajar siswa. Hal ini dibuktikan dengan adanya peningkatan rata-rata tiap siklusnya. Ratarata siklus I sebesar $62,54 \%$ dengan kategori "aktif", meningkat pada siklus II sebesar 78,27\% termasuk kategori "aktif", dengan peningkatan sebesar $15,73 \%$.

2. Penerapan model cooperative learning tipe think pair share dalam pembelajaran matematika dapat meningkatkan hasil belajar siswa kelasVI SD Negeri Kaliwadas 01 yang dapat diketahui dari nilai rata-rata hasil belajar siswa dan persentase ketuntasan hasil belajar siswa secara klasikal. Nilai rata-rata hasil belajar siswa pada siklus I sebanyak 25 siswa tuntas $(56,82 \%)$ dengan rata-rata $61,70 \%$. Siklus II sebanyak 37 siswa tuntas $(84,09 \%)$ dengan rata-rata 78,61\%. Peningkatan persentase ketuntasan hasil belajar sebesar $27,27 \%$ dan peningkatan rata-rata sebesar $6,91 \%$. 


\section{b. Saran}

Berdasarkan kesimpulan yang telah diuraikan di atas, peneliti memberikan saran antara lain:

1. Bagi siswa, dapat selalu aktif dan menunjukkan partisipasinya dalam mengikuti kegiatan pembelajaran sehingga dapat menghasilkan pengetahuan yang bersifat komperehensif baik kognitif, afektif, dan psikomotor. Siswa diharapkan dapat bertanggung jawab akan tugas yang diberikan guru baik tugas individu (think) maupun kelompok dan dapat bekerja sama dalam tim belajar secara berpasangan (pair) dan berkelompok. Peningkatan yang ditunjukkan dalam penerapan tipe think pair share dengan media grafis dapat meningkatkan aktivitas dan hasil belajar siswa secara optimal baik secara individu (think), berpasangan (pair) maupun berbagi dengan kelompok saling berbagi (share).

2. Bagi guru, terdapat beberapa hal yang pelu diperhatikan sebagai pelaksanaan penerapan tipe think pair share adalah perlu mempersiapkan segala perangkat pembelajaran dan media yang mendukung yang disesuaikan dengan tema maupun subtema yang akan dibahas dan mengaitkannya dengan kehidupan siswa sehingga semua mata pelajaran dapat terkait secara harmonis. Diharapkan pada penerapan tipe ini lebih mengoptimalkan partisipasi aktif siswa dalam belajar baik secara individu, berpasangan (pair) maupun pada tahap berbagi dengan kelompok (share). Guru lebih memfasilitasi dan membimbing siswa dalam kelompok saat mempresentasikan hasil diskusi sehingga ide-ide dapat menyebar.

3. Bagi sekolah, pengoptimalan sarana dan prasarana serta penyediaan alat dan media sebagai penunjang yang mendukung pelaksanaan pembelajaran agar siswa lebih aktif dan termotivasi dalam penerapan tipe think pair share dan media grafis.

4. Bagi peneliti lanjutan, dapat mengembangkan dan menjadi sumber perbaikan pembelajaran dengan menerapkan model pembelajaran sejenis pada kelas lain atau pada materi lain.

\section{DAFTAR PUSTAKA}

Huda, Miftahul. 2013. Modelmodel Pengajaran dan Pembelajaran. Pustaka Pelajar. Yogyakarta.

Isjoni. 2007. Cooperative Learning. Alfabeta. Bandung. Isjoni. 2010. Cooperative Learning. Alfabeta. 
ISSN 2442-5419 Vol. 4, No. 2 (2015) 72-83

Kunandar. 2011. Penelitian

Tindakan Kelas. Rajawali

Pers. Jakarta.

Mulyasa. 2011. Praktik Penelitian

Tindakan Kelas. Bandung:

PT Remaja Rosdakarya.

Muslikah. 2010. Sukses Profesi

Guru Dengan Penelitian

Tindakan Kelas.

Interprebook. Yogyakarta.

Sagala, S. 2010. Konsep Dan

Makna Pembelajaran.

Alfabeta. Jakarta

Sumantri, M., dan Nana, S. 2007.

Materi Pokok

Perkembangan Peserta

Didik. Universitas Terbuka.

Jakarta.

Suprayekti. 2004. Penerapan

Model Pembelajaran

Interaktif Pada Mata

Pelajaran MATEMATIKA di

$S D$. Universitas Negeri

Jakarta. Jakarta. 